\title{
Physico-chemical properties lime-ammonium nitrate based on chalk, nitrate and ammonium sulphate
}

\author{
Oybek Rasulov ${ }^{1}$, Abdurasul Mamataliyev ${ }^{1 *}$, Dilnavoz Rasulova ${ }^{1}$, Uktam Temirov $^{2}$ and \\ Shafaat Namazov ${ }^{1}$ \\ ${ }^{1}$ Institute of General and Inorganic Chemistry of Academy Sciences of Uzbekistan, Mirzo-Ulugbek \\ district, $100170,77^{\mathrm{a}}$, Republic of Uzbekistan. \\ ${ }^{2}$ Navoi State Mining Institute, 210100, Galaba Str. 27, Republic of Uzbekistan
}

\begin{abstract}
For the granulation of nitrate-sulfate-carbonate melt, the prilling method is applied using a granulation tower. The composition and properties of new types of fertilizers were studied. It is shown that with the ratio $\mathrm{NH}_{4} \mathrm{NO}_{3}: \mathrm{CaCO}_{3}:\left(\mathrm{NH}_{4}\right)_{2} \mathrm{SO}_{4}=100: 24: 1$ the product contains $28,03 \%-\mathrm{N}, 0,50 \%-\mathrm{SO}_{3}, 10 \%-\mathrm{CaO}$ and has a granule strength of 6.03 $\mathrm{MPa}$, which is much higher than the strength of pure $\mathrm{NH}_{4} \mathrm{NO}_{3}$ granules $(1.32 \mathrm{MPa})$. The absorption of pure AN granules is $4.82 \mathrm{~g}$. With an increase in the proportion of chalk and ammonium sulfate to the $\mathrm{NH}_{4} \mathrm{NO}_{3}$ : $\mathrm{CaCO}_{3}:\left(\mathrm{NH}_{4}\right)_{2} \mathrm{SO}_{4}=100: 24: 1$ ratio, the absorbency of the LAN granules is $2.57 \mathrm{~g}$.
\end{abstract}

\section{Introduction}

Ammonium nitrate is the world's most widespread and effective nitrogen fertilizer. In 2007, its global production capacity amounted to 43 million tons per year [1].

In Uzbekistan, the aggregate capacities of three plants producing ammonium nitrate (JSC "Maksam-Chirchik", "Navoiazot", and "Ferganaazot") exceeded 1 million 750 thousand tons per year [2].

It is used in agriculture for all types of crops and on all types of soil. But it has one very serious drawback - explosiveness [3].

The explosion of ammonium nitrate at a warehouse of a chemical enterprise in Toulouse (France) in 2001, a series of terrorist attacks in Southeast Asia, Russia, Uzbekistan, and other countries using ammonium nitrate as explosive put consumers and producers of fertilizers in a difficult position. Several countries - China, the Philippines, Colombia, Ireland, and Algeria, have banned the use of ammonium nitrate in agriculture. In this regard, the requirements for the quality of ammonium nitrate and its storage conditions were tightened. And the manufacturers have been tasked with ensuring the transition to the production of fertilizers based on ammonium nitrate, which retains agrochemical

\footnotetext{
*Corresponding author:abdirasul.86@mail.ru
} 
efficiency, with significantly greater resistance to external influences and, accordingly, less explosiveness.

Currently, Uzbekistan has established the production of NPF (nitrogen-phosphorus fertilizer with a content of 22-28\% $\mathrm{N}$ and 2-6\% $\mathrm{P}_{2} \mathrm{O}_{5}$ ) [4-7] and LAN (lime-ammonium nitrate with a content of $22-28 \% \mathrm{~N}$ ) $[8,9]$ by introducing ammonium nitrate into the melt before prilling carbonate phosphorite flour $\left(17-18 \% \mathrm{P}_{2} \mathrm{O}_{5}\right)$ or lime flour on the granite tower.

The following substances are used as additives that reduce the level of the potential hazard of ammonium nitrate: carbonate-containing compounds of natural and technogenic origin (chalk, calcium carbonate, dolomite); potassium-containing substances (chloride and potassium sulfate); substances containing the cation of the same name - ammonium (ammonium sulfate, ortho-, and ammonium polyphosphates); other ballast substances that do not carry a payload, but determine only the mechanical dilution of ammonium nitrate (gypsum, phosphogypsum, etc.) [10].

The most widespread are the additives of the first group in producing the so-called limeammonium nitrate [11-13].

In Europe, it is produced by 31 firms, in Russia - by five industrial enterprises.

Earlier [14-16], we studied the composition and properties of LAN obtained based on ammonium nitrate $\left(\mathrm{NH}_{4} \mathrm{NO}_{3}\right)(34.96 \% \mathrm{~N})$ and limestone flour $\left(\mathrm{CaCO}_{3}\right)$, "Karmana," "Zhamansay," "Ovkhona," "Forish" and "Karnab" deposits of Uzbekistan. It is shown that depending on the mass ratio $\mathrm{NH}_{4} \mathrm{NO}_{3}: \mathrm{CaCO}_{3}=100$ : (5-80), the nitrogen content in the products obtained varies within the range of $33.3-18.8 \%$. When the Karmaninskaya limestone flour is added to the $\mathrm{AN}$ melt at the ratio $\mathrm{NH}_{4} \mathrm{NO}_{3}: \mathrm{CaCO}_{3}=100:(5-80)$, the strength of the granules is $3.52-8.45 \mathrm{MPa}$, and for Zhamansai, Ovkhoninskaya, Forishskaya, and Karnabskaya flours 2.32-6.41, 2.76-9.57, 3.02-7.77 and 2.83-7.31 MPa, respectively. With the studied $\mathrm{NH}_{4} \mathrm{NO}_{3}: \mathrm{CaCO}_{3}$ ratios, the caking of finished products based on Karmaninsky limestone is in the range of $2.34-3.58 \mathrm{~kg} / \mathrm{sm}^{2}$, which is $1.3-2$ times less than the caking of standard nitrate with the addition of $0.28 \% \mathrm{MgO}\left(4.67 \mathrm{~kg} / \mathrm{sm}^{2}\right)$. The proposed mechanism of action of limestone additives, which increase the strength of AN granules and at the same time reduce its caking, is based on the creation of many crystallization centers, which accelerates the crystallization process and causes the formation of small crystals that make the granules denser and stronger.

This work aims to expand the field of application of carbonate compounds and improve the quality, increase the thermal stability of the LAN and increase the content of the fourth nutrient, sulfur, in the fertilizer.

\section{Materials and methods}

In laboratory conditions, we used $\mathrm{NH}_{4} \mathrm{NO}_{3}$ grade "pure" $(34.96 \% \mathrm{~N})$ as starting raw materials, as well as powdered chalk with the composition (wt\%): $\mathrm{CaO} 52.23 ; \mathrm{MgO} 1.11$; $\mathrm{CO}_{2}$ 41.5. To obtain samples of chalk-containing LAN, the experiments were carried out as follows: a weighed portion of $\mathrm{NH}_{4} \mathrm{NO}_{3}$ was melted in a metal cup by electric heating. Then $\left(\mathrm{NH}_{4}\right)_{2} \mathrm{SO}_{4}$ and chalk were introduced into the melt at the mass ratios $\mathrm{NH}_{4} \mathrm{NO}_{3}: \mathrm{CaCO}_{3}$ : $\left(\mathrm{NH}_{4}\right)_{2} \mathrm{SO}_{4}=100:(2-58):(0.5-2.0)$. Then, the nitrate-carbonate-sulfate melt was kept at $175-180^{\circ} \mathrm{C}$ for $1-1.5$ minutes. Then it was poured into a laboratory granulator, which is a metal beaker with a perforated bottom, the diameter of the holes in which was $1.2 \mathrm{~mm}$. The pump created pressure in the upper part of the glass, and the melt was sprayed from a height of $35 \mathrm{~m}$ onto a plastic film lying on the ground. The resulting granules were sieved by particle size. Particles $2-3 \mathrm{~mm}$ in size were tested for strength according to GOST 21560.2-82. Then the products were crushed and analyzed according to known methods [17]. 
The $\mathrm{pH}$ value of $10 \%$ aqueous suspensions of the studied samples was measured on an I$130 \mathrm{M}$ laboratory ionometer with an electrode system of ESL 63-07, EVL-1M3.1, and TKA-7 electrodes with an accuracy of $0.05 \mathrm{pH}$ units.

The accumulation of fertilizers was determined using the express method [18]. Sagging $\left(\mathrm{X}-\mathrm{kg} / \mathrm{cm}^{2}\right.$ ) was calculated using formula: $\mathrm{X}=\mathrm{P} / \mathrm{S}$ where, $\mathrm{P}$ - breaking force, $\mathrm{H}$ (kgf); $\mathrm{S}$ is the cross-sectional area of the sample, $\mathrm{sm}^{2}$.

The absorbency of the granules about liquid fuel (diesel oil) was determined according to the procedure provided by TU 6-03-372-74 for granular porous AN grade "P." This indicator is expressed in the number of grams that $100 \mathrm{~g}$ of granules $(\mathrm{g} / 100 \mathrm{~g})$ can absorb.

The temperature of the onset of decomposition of the obtained fertilizers was determined using a NETSCH STA 409 PC / PG device (Germany) in aluminum crucibles at a sample heating rate of $2 \mathrm{deg} / \mathrm{min}$, a sample weight of $10-16 \mathrm{mg}$. The thermal stability of granules to repeated heating-cooling cycles in the range of $20-60^{\circ} \mathrm{C}$ was determined according to the method described in [19].

The rate of dissolution of sample granules in water was determined as follows. The fertilizer granule was dipped into a glass with $100 \mathrm{ml}$ of distilled water, in which its complete dissolution was visually observed and recorded. Room temperature tests five times. Granular samples of $\mathrm{NH}_{4} \mathrm{NO}_{3}$ (without additive) and $\mathrm{AN}$ (with the addition of $0.28 \%$ $\mathrm{MgO}$ ) were selected as samples for comparison with the studied samples. The results are shown in the table and figure.

It can be seen from Table 1 that in the studied ranges of the $\mathrm{NH}_{4} \mathrm{NO}_{3}: \mathrm{CaCO}_{3}:\left(\mathrm{NH}_{4}\right)_{2} \mathrm{SO}_{4}$ $=100:(2-58):(0.5-2.0)$ ratios, the products contain $22.04-34.19 \%$ nitrogen, $1.02-18.90 \%$ $\mathrm{CaO}$ and $0.3-0.8 \% \mathrm{SO}_{3}$. Sulfur is a part of proteins and amino acids during the formation of the crop.

Table 1. Composition of calcium ammonium nitrate

\begin{tabular}{|c|c|c|c|c|c|}
\hline $\begin{array}{c}\text { Mass ratio } \\
\mathrm{NH}_{4} \mathrm{NO}_{3}: \mathrm{CaCO}_{3}:\end{array}$ & \multicolumn{5}{|c|}{ Content in products, \% } \\
\cline { 2 - 6 }$\left(\mathrm{NH}_{4}\right)_{2} \mathrm{SO}_{4}$ & $\mathrm{~N}_{\text {totol. }}$ & $\mathrm{N}_{\text {ammonia. }}$ & $\mathrm{N}_{\text {nitrate. }}$ & $\mathrm{SO}_{3}$ & $\mathrm{CaO}_{\text {totol. }}$ \\
\hline $\mathrm{NH}_{4} \mathrm{NO}_{3}$ brand "h" & 34.96 & 17.48 & 17.48 & - & - \\
\hline $100: 2.0: 0.5$ & 34.19 & 17.18 & 17,10 & 0.30 & 1.02 \\
\hline $100: 5.0: 0.5$ & 33.12 & 16.67 & 17.45 & 0.287 & 2.49 \\
\hline $100: 9.0: 0.5$ & 32.0 & 16.12 & 18.88 & 0.277 & 4.31 \\
\hline $100: 15: 0.5$ & 30.06 & 15.13 & 14.93 & 0.262 & 6.75 \\
\hline $100: 24: 1.0$ & 28.03 & 14.19 & 13.84 & 0.50 & 10.0 \\
\hline $100: 29: 1.0$ & 27.0 & 13.65 & 13.35 & 0.465 & 11.63 \\
\hline $100: 34: 1.0$ & 26.04 & 13.14 & 12.90 & 0.446 & 13.14 \\
\hline $100: 45: 2.0$ & 24.05 & 12.32 & 11.73 & 0.823 & 15.96 \\
\hline $100: 58: 2.0$ & 22.04 & 11.28 & 10.76 & 0.758 & 18.90 \\
\hline
\end{tabular}

\section{Results and Discussions}

In terms of its physiological role in plant nutrition, sulfur should be ranked fourth after nitrogen, phosphorus, and potassium [20]. And the calcium in importance for plant nutrition is in fifth place after nitrogen, phosphorus, potassium, and sulfur. If it is introduced into the soil in a form assimilable for plants, it will significantly increase yield [21]. Thus, we can say that the composition of the $\mathrm{AN}$ is additionally enriched with two macroelements sulfur and calcium. This suggests that when the $\mathrm{NO}_{3}-$ anion is bound by alkaline cations $(\mathrm{Ca}+)$ of chalk, the $\mathrm{pH}$ value rises to a value that approaches the aqueous suspensions of chalk. It can be assumed that the carbonate raw material neutralizes the acidity of the AN. 
The discovered property of the samples can provide a decrease in soil "acidification" after application of the AN.

The main properties (strength, temperature of the onset of decomposition, dissolution rate, caking, porosity, and adsorption absorption of liquid fuel granules) of ammonium sulfate LAN are studied in the figure. It was found that the addition of any amount of $\left(\mathrm{NH}_{4}\right)_{2} \mathrm{SO}_{4}$ and chalk sharply reduces caking, porosity, absorbency, increases the strength and temperature of the onset of decomposition of nitrate granules. If the strength of the granules of the industrial $\mathrm{AN}$ is $1.58 \mathrm{MPa}$, then at $\mathrm{NH}_{4} \mathrm{NO}_{3}: \mathrm{CaCO}_{3}:\left(\mathrm{NH}_{4}\right)_{2} \mathrm{SO}_{4}=100$ : $2.0: 0.5$, this indicator increases to $2.69 \mathrm{MPa}$, at $100: 9.0: 0.5$ to $4.76 \mathrm{MPa}$, at $100: 24:$ 1.0 to $6.03 \mathrm{MPa}$, at $100: 34: 1$ up to $7.0 \mathrm{MPa}$, and at $100: 45: 2$ up to $7.0 \mathrm{MPa}$. The greatest effect of granule strength $-8.93 \mathrm{MPa}$ is achieved at $\mathrm{NH}_{4} \mathrm{NO}_{3}: \mathrm{CaCO}_{3}:\left(\mathrm{NH}_{4}\right)_{2} \mathrm{SO}_{4}$ $=100: 58: 2$ (Fig., $a$ ). All this indicates a decrease in the tendency of the fertilizer to detonate, which is explained by a decrease in the size of the crystals, providing them with a denser packing and the presence of chalk and ammonium sulfate in the mixture, which interrupt the homogeneity of the properties of the AN and the zone of propagation of the detonation wave.

It follows from Fig., $b$ that the addition of any amount of $\left(\mathrm{NH}_{4}\right)_{2} \mathrm{SO}_{4}$ significantly reduces the caking of the AN (from 2.41 to $0.33 \mathrm{~kg} / \mathrm{sm}^{2}$ ), which is $2-14$ times less than the caking of standard nitrate with the addition of $0.28 \% \mathrm{MgO}\left(4.67 \mathrm{~kg} / \mathrm{sm}^{2}\right)$.

Another indicator characterizing the quality of a thermostable speaker is the adsorption capacity of granules for liquid fuel. The lower the porosity of the granules, the lower their absorbency should be. As the data in Fig. $c$., such a provision is indeed linked. Depending on the weight ratio of the initial components, the absorbency of granules of ammonium sulfate LAN ranges from 1.75-3.24 $\mathrm{g}$ of fuel to $100 \mathrm{~g}$ of the product. It is $4.82 \mathrm{~g}$ for granular $\mathrm{NH}_{4} \mathrm{NO}_{3}$.

With an increase in the mass fraction of chalk and ammonium sulfate in the $\mathrm{NH}_{4} \mathrm{NO}_{3}$ melt from $100: 2: 0.5$ to $100: 58: 2$, the decomposition start temperature increases from $210^{\circ} \mathrm{C}$ for pure $\mathrm{NH}_{4} \mathrm{NO}_{3}$ to $232.9-266.2^{\circ} \mathrm{C}$ in the finished product (Fig. $d$ ). This means that the higher the strength and temperature of the beginning of the decomposition of the granules, the less diesel fuel gets inside the granules. As a result, the less the detonation ability of nitrate ammonium.
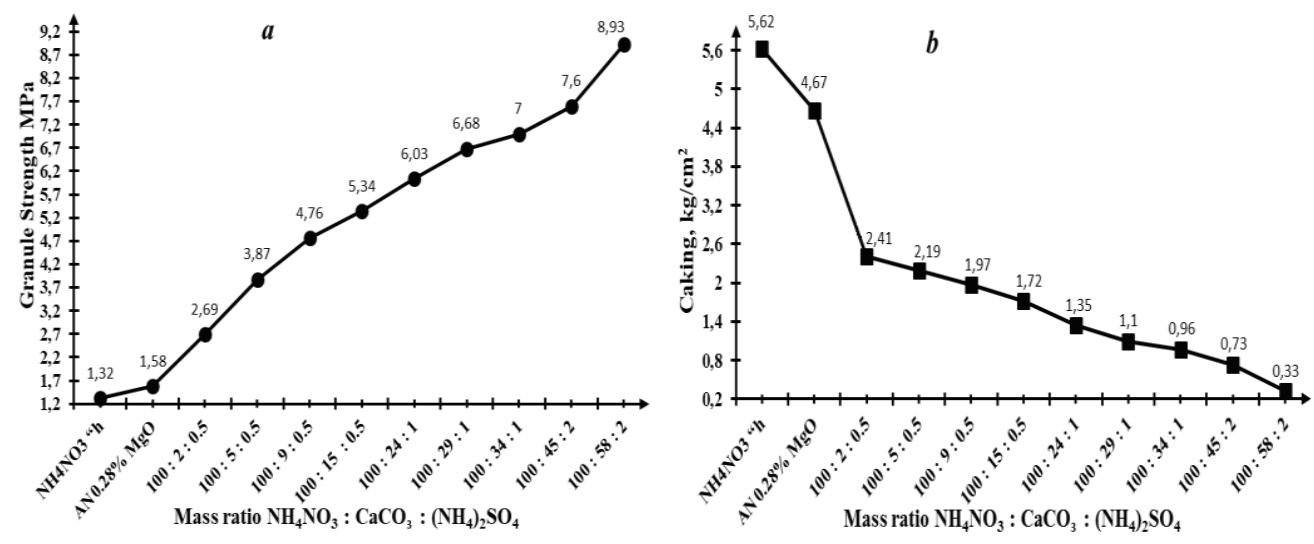

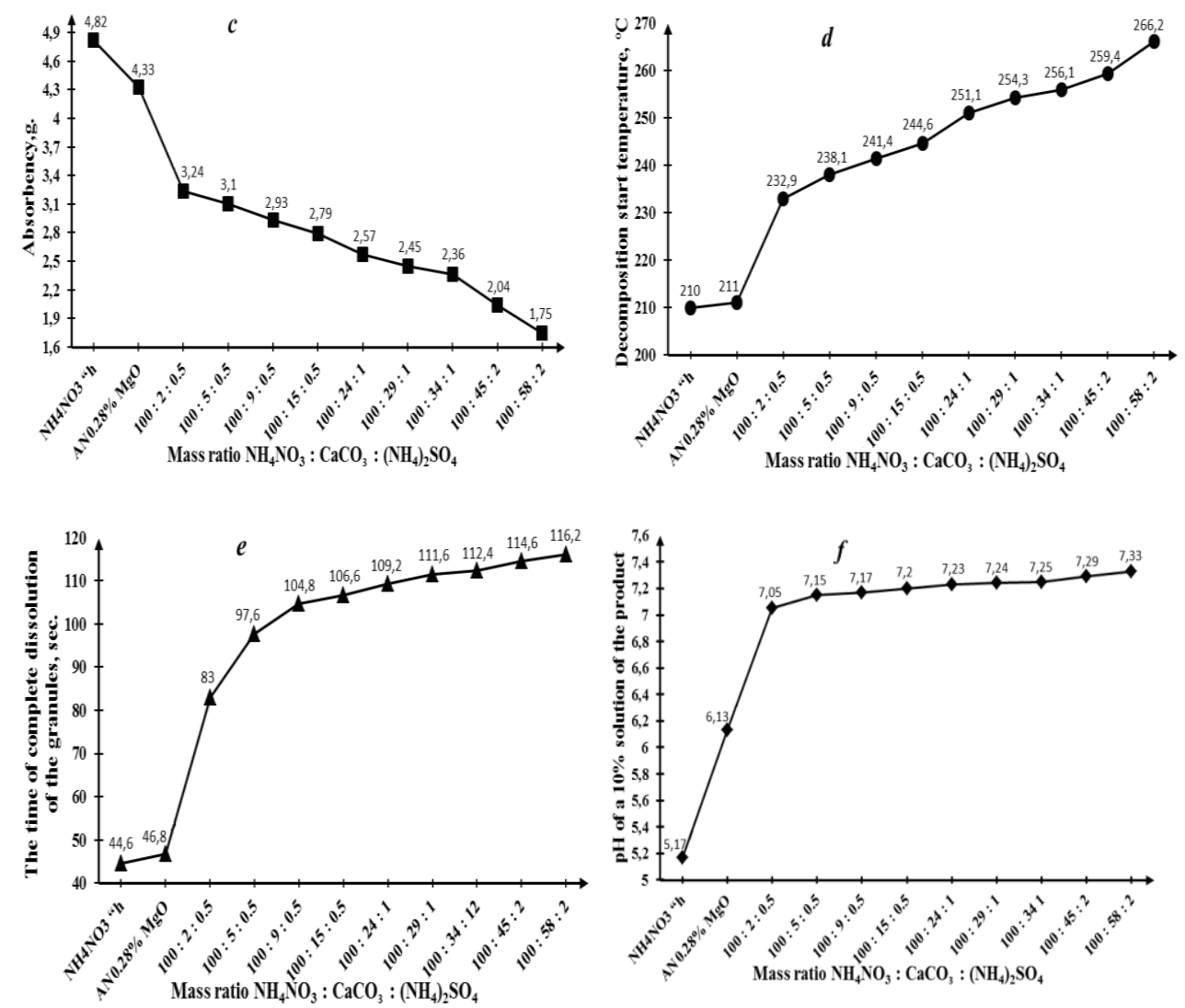

Fig. 1. The influence of the weight ratio of $\mathrm{NH}_{4} \mathrm{NO}_{3}: \mathrm{CaCO}_{3}:\left(\mathrm{NH}_{4}\right)_{2} \mathrm{SO}_{4}$ on strength (a), caking (b), absorbency (c), temperature onset of decomposition (d), time of complete dissolution of granules of ammonium nitrate (e) and $\mathrm{pH}$ of a $10 \%$ solution of the product (f).

As the data in Fig. $e$, the presence of chalk and ammonium sulfate in the composition of nitrate affects the dissolution rate of the latter's granules. With an increase in the amount of $\mathrm{CaCO}_{3}$ and $\left(\mathrm{NH}_{4}\right)_{2} \mathrm{SO}_{4}$ in the $\mathrm{NH}_{4} \mathrm{NO}_{3}$ melt, the time for the complete dissolution of the finished product granules in water increases. The complete dissolution of granules of pure $\mathrm{NH}_{4} \mathrm{NO}_{3}$ and $\mathrm{AN}$ with a magnesian additive $(0.28 \% \mathrm{MgO})$ in water is $44.6 \mathrm{sec}$ on average and $46.8 \mathrm{sec}$, accordingly, and with the addition of chalk and ammonium sulfate in an amount from 2 and 0.5 to 58 and $2 \mathrm{~g}$, slows down the dissolution rate of product granules from 83 to $116.2 \mathrm{sec}$. This means that $\mathrm{AN}$ granules containing chalk and ammonium sulfate dissolve much more slowly in the soil solution. Therefore, the presence of chalk and ammonium sulfate in the nitrate promotes the gradual release of nitrogen from the granule.

In addition, the addition of chalk and ammonium sulfate to the $\mathrm{NH}_{4} \mathrm{NO}_{3}$ melt increases the $\mathrm{pH}$ of a $10 \%$ solution of the latter from 5.17 to $7.05-7.33$ (Fig. $f$ ), and this is most effective in neutral and acidic soils.

\section{Conclusion}

Research has been carried out to obtain sulfur-containing lime-ammonium nitrate based on ammonium nitrate and powdered chalk, and ammonium sulfate. It was found that the more powdered ammonium sulfate and chalk are introduced into the ammonium nitrate melt, the 
lower the $\mathrm{N}$ content and the higher the $\mathrm{S}$ and $\mathrm{CaO}$ content in the product. It was also shown that the greater the amount of ammonium sulfate and chalk, the lower the caking and absorbency of diesel oil, and the higher the strength, thermal stability, water solubility, and decomposition temperature of nitrate granules. Thus, the samples of sulfur-containing limeammonium nitrate have improved physicochemical, agrochemical, and lower detonation properties.

\section{References}

1. Chernyshev A.K., Levin B.V., Tugolukov A.V., Ogarkov A.A., Ilyin V.A. Ammonium nitrate: properties, production, application // M.: ZAO INFOCHIM. 544 p. (2009)

2. Mamataliyev A.A., Sherkuziyev D.Sh., Beglov B.M., Namazov Sh.S. Nitrogen Potassium and Nitrogenpotassiumsulfur Containing Complex Fertilizers on the base of Melt Ammonium Nitrate, Potassium Chloride and Phosphogypsum // International Journal of Advanced Science and Technology. Austria. - Vol. 29. - No. 8.. - PP. 1468-1475, (2020)

3. Lavrov V.V., Shvedov K.K. On the explosion hazard of ammonium nitrate and fertilizers based on it // Scientific and technical news: JSC INFOCHEM - Special issue.- No. 2. - PP. 44-49, (2004)

4. Sh.S. Namazov, B.B. Botirov, V.V. Pak, Sh.I. Salikhov, A.M. Reimov, R. Yakubov, B.M. Beglov, R.K. Kurbaniyazov, N.N. Pirmanov, B.S. Zakirov. Patent No. 04527 RUz. Cl. 8C05G 1/00, C05B 7/00. C05C 1/00. A method of obtaining nitrogenphosphorus fertilizer. Bul. No. 7, (2012)

5. Kurbaniyazov R.K., Reimov A.M., Dadahodzhaev A.T., Namazov Sh.S., Beglov B.M. Nitrogen-phosphorus fertilizers obtained by introducing phosphate raw materials of the Central Kyzyl Kum into ammonium nitrate melt // Chemical Industry. St. Petersburg.- T. 84. - No. 5. - PP. 242-248, (2007)

6. Kurbaniyazov R.K. Complex nitrogen-phosphorus fertilization technology based on ammonium nitrate and phosphorites of the Central Kyzyl Kum. Abstract of the dissertation, Cand. tech. Sciences, IGIKh AS RUz. - Tashkent. - 28 p, (2011)

7. Temirov, U. S., Namazov, S. S., Usanbayev, N. K. Intensive technology for processing bird litter in organomineral fertilizers. Izvestiya vysshikh uchebnykh zavedenii khimiya khimicheskaya tekhnologiya, -2020, 63(12), -P. 85-94. https://doi.org/10.6060/ivkkt.20206312.6210

8. Zhuraev N.Y. Development and implementation of technology for export-oriented modified ammonium nitrate with the addition of local limestone: Dis. tech. Sciences (PhD). - Tashkent. - 2020. - $101 \mathrm{p}$.

9. Nabiev A.A. Technology of obtaining thermostable ammonium nitrate with dolomite addition: Dis. tech. Sciences (PhD). -120 p., Tashkent (2019)

10. Levin B.V., Sokolov A.N. Problems and technical solutions in the production of complex fertilizers based on ammonium nitrate. // The world of sulfur, N, P and K.No. 2. - pp. 13-21. (2004)

11. Zhmay L., Khristianova E. Ammonium nitrate in Russia and in the world. Modern situation and prospects // The world of sulfur, N, P and K.- No. 2. - pp. 8-12., (2004).

12. Nabiev A.A., Reimov A.M., Namazov Sh.S., Mamataliev A.A. Physicochemical and commercial properties of magnesium-containing lime ammonium nitrate // UNIVERSUM, technical sciences, electronic scientific journal. -- No. 5 (38). - pp. 40-45., Russia. (2017)

13. Nabiev A.A., Reymov A.M., Juraev N.Yo., Mamataliev A.A., Seytnazarov A.R., Namazov Sh.S. Composition and properties of magnesium-containing carbonate- 
ammonium nitrate. International Journal of Recent Advancement in Engineering \& Research.- Volume 04. - Issue 06 - pp. 1-6. India. (2018)

14. Juraev N.Yo., Mamataliyev A.A., Namazov Sh.S. Granular carbonate-ammanium nitrate based on melt ammonium nitrate and limestone // LVII International correspondence scientific and practical conference "European research: innovation in science, education and technology" London, United Kingdom. 6-7 - pp. 7-10. November (2019)

15. Zhuraev N.Yo., Mamataliev A.A., Namazov Sh.S. Granular lime-ammonium nitrate based on a melt of ammonium nitrate and limestone // Electronic scientific journal. UNIVERSUM. Technical science. -No. 9 (54). - pp. 41-45. Russia. (2018)

16. Juraev N.Yo., Mamataliyev A.A., Namazov Sh.S. Composition and commodity property of carbonate-ammonium nitrate fertilizers on a basis of ammonium nitrate melt and limestone // LXIV International correspondence scientific and practical conference «International scientific review of the problems and prospects of modern science and education. Boston, USA. 20-21- PP. 14-17. November (2019)

17. MM Vinnik, LN Erbanova, PM Zaitsev et al. Methods of analysis of phosphate raw materials, phosphoric and complex fertilizers, feed phosphates. - M.: - 213 p. (1975)

18. Olevsky V.M., Polyakov N.N. and others. Results of industrial tests of ammonium nitrate for caking and friability // Abstract collection "Nitrogen industry". // M.: NIITEKHIM.-pp. 6-8. (1974)

19. Cherny V.A., Streltsov O.A. Application of aerosil for modification of nitrogencontaining mineral fertilizers // Chemical technology.- No. 2. - pp. 47-49. (1988)

20. Milashchenko N.Z. Ammonium sulfate is a promising form of nitrogen fertilizer // Agrochemical Bulletin. - 2004. - No. 2. - pp. 3.

21. Kopeikina A.N. The value of secondary nutrients for agricultural crops // Chemical industry abroad - M. - No. 1. - pp. 26-44. (1984) 